\title{
Cervical ganglioneuroma: clinical and radiological features of a rare tumour
}

\author{
Mohamed Badri, Ghassen Gader, Kamel Bahri, Ihsen Zammel
}

Department of Neurosurgery, Trauma and Burns Center, Ben Arous, Tunisia

Correspondence to Dr Mohamed Badri, badri.med@gmail.com

Accepted 14 December 2017

\section{DESCRIPTION}

Ganglioneuromas are rare benign tumours of neurogenic origin that most frequently develop in the cervical sympathetic chain, ${ }^{1} 2$ with genetic associations demonstrated with Neurofibromatosis type 1 (NF-1). We report the case of a 41-year-old woman with a history of cavum neoplasm at the age of 23. This tumour was classified after assessment of extension as T1N0M0 (tumour, node, metastases). Pathological examination of a biopsy concluded to a keratinising squamous cell carcinoma. The patient was then irradiated (2D Cobalt radiotherapy). The patient presented with gait trouble that appeared a few weeks ago. Clinical examination found a Brown-Séquard syndrome with paresis and loss of proprioception on the left side, and loss of pain and temperature sensation on the right side. Medullar MRI (figures 1 and 2) showed an intradural extramedullary well-circumscribed mass with an hourglass shape from C5 to C6 extending through the left neural foramina. T1-weighted images show

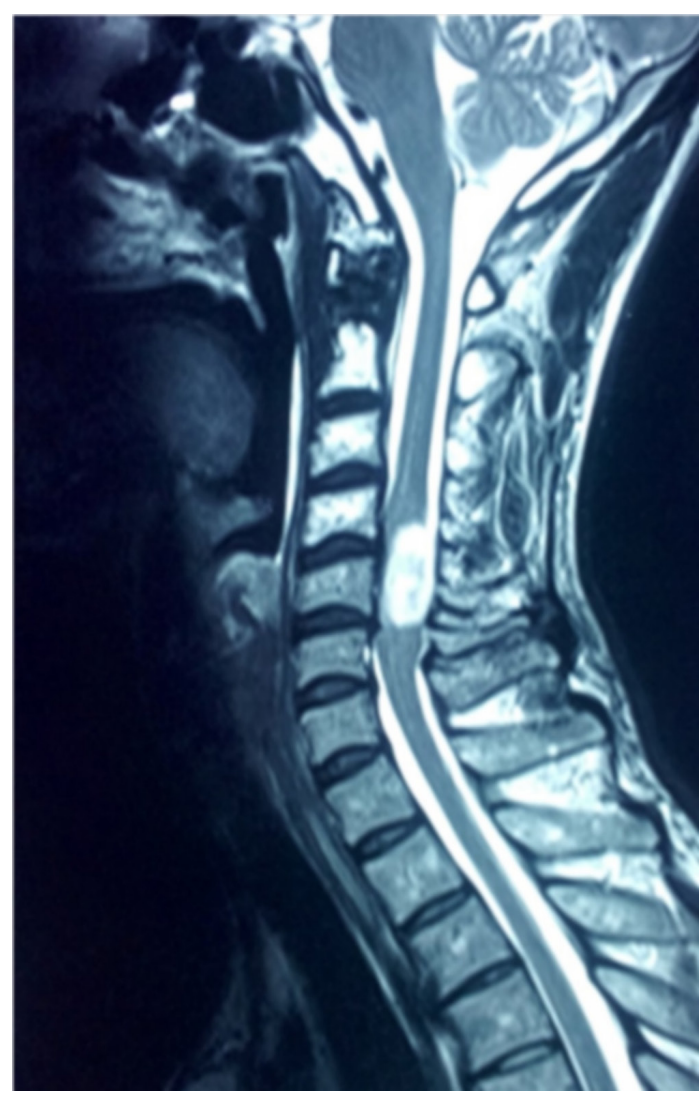

Figure 1 MRI on T2-weighted sequences in sagittal section shows an hyperintense mass at the levels of C4 and $C 5$ with hourglass appearance. homogeneous hypointense signals, T2-weighted images show heterogeneous hyperintense signals and gadolinium-enhanced images show mildly heterogeneous enhancement. A laminectomy from C4 to C6 was performed with total resection of the tumour. Postoperative course was marked by a complete recovery of the patient. Pathological examination concluded to a ganglioneuroma. Imaging provides valuable information on the size, location, composition of the mass and its relationship to adjacent significant structures, which is helpful in determining a surgical plan. On CT scan, ${ }^{1}$ ganglioneuromas are homogeneous, well-circumscribed masses with heterogeneous enhancement after contrast, and calcifications are seen in about $30 \%$ of cases. CT imaging may reveal punctate calcifications, which are missing in neuroblastomas.

On MRI, the differential diagnosis of an enhancing dumbbell-shaped mass in the spinal canal extending through the neural foramina includes neurogenic tumours, of which neurofibromas are the most common. Although rare, ${ }^{1}$ spinal ganglioneuromas need to be considered for any large mass occupying both the intraspinal and extraspinal compartments, even out of the context of neurofibromatosis. Total surgical resection is the treatment of choice for ganglioneuroma. Surgical decompression of the spinal cord must be undertaken as soon as possible. ${ }^{2}$ Subtotal resection is feasible when total excision is deemed risky. ${ }^{3}$ Some authors attest that ganglioneuromas may be associated with previous

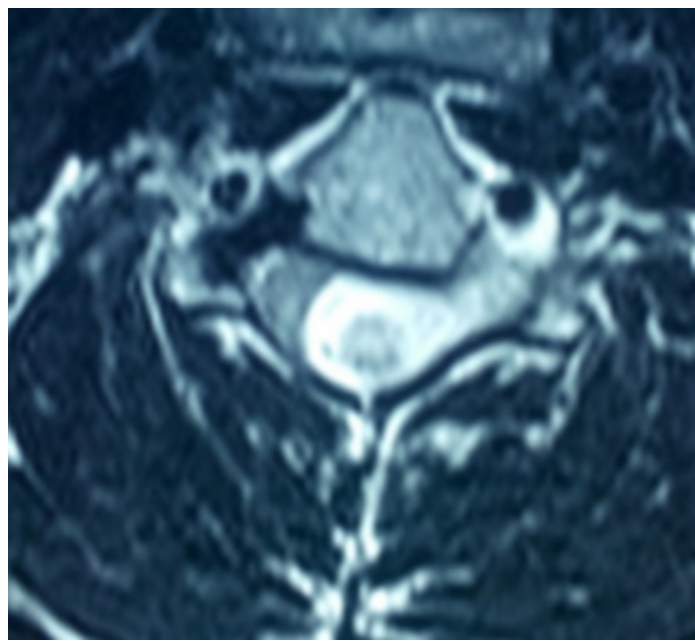

Figure 2 MRI on T1-weighted sequences in axial section reveals a left lateralised intradural extramedullary mass with intense enhancement after injection of gadolinium, with an extracanal extension. 
radiotherapy. In this case, they appear after an average time of 18 years after irradiation.

Further therapy, chemotherapy or radiotherapy, is not usually required, even for cases with partial excision.

\section{Learning points}

- Diagnosis of ganglioneuromas must be discussed at all cervical medullar masses despite of its rarity.

- An enhancing dumbbell-shaped mass in the spinal canal extending through the neural foramina has to lead to think about ganglioneuroma.

Contributors MB and GG: wrote the manuscript. KB: did the bibliographic research and corrected the manuscript. IZ: corrected the manuscript.
Competing interests None declared.

\section{Patient consent Obtained.}

Provenance and peer review Not commissioned; externally peer reviewed.

(C) BMJ Publishing Group Ltd (unless otherwise stated in the text of the article) 2018. All rights reserved. No commercial use is permitted unless otherwise expressly granted.

\section{REFERENCES}

1 Rodriguez FJ, Folpe AL, Giannini C, et al. Pathology of peripheral nerve sheath tumors: diagnostic overview and update on selected diagnostic problems. Acta Neuropathol 2012;123:295-319

2 Son DW, Song GS, Kim YH, et al. Ventrally located cervical dumbbell ganglioneuroma producing spinal cord compression. Korean I Spine 2013;10:246.

3 Keller SM, Papazoglou S, McKeever P, et al. Late occurrence of malignancy in a ganglioneuroma 19 years following radiation therapy to a neuroblastoma. J Surg Oncol 1984:25:227-31.

Copyright 2017 BMJ Publishing Group. All rights reserved. For permission to reuse any of this content visit

http://group.bmj.com/group/rights-licensing/permissions.

BMJ Case Report Fellows may re-use this article for personal use and teaching without any further permission.

Become a Fellow of BMJ Case Reports today and you can:

- Submit as many cases as you like

- Enjoy fast sympathetic peer review and rapid publication of accepted articles

- Access all the published articles

- Re-use any of the published material for personal use and teaching without further permission

For information on Institutional Fellowships contact consortiasales@bmjgroup.com

Visit casereports.bmj.com for more articles like this and to become a Fellow 